\title{
TEKNOLOGI, BENTUK, FUNGSI, DAN MOTIF HIAS TEMBIKAR DI ISTANA ALMUKARRAMMAH, SINTANG
}

\section{TECHNOLOGY, FORM, FUNCTION, AND DECORATION OF POTTERY IN ALMUKARRAMMAH PALACE,SINTANG}

\author{
Ulce Oktrivia \\ BalaiArkeologi Kalimantan Selatan, Jl. Gotong Royong II,RT 03/06 Banjarbaru 70711, Kalimantan Selatan \\ email: ulce.oktrivia@kemdikbud.go.id
}

Diterima 15 September 2016

Direvisi 26 Oktober 2016

Disetujui 27 Oktober 2016

\begin{abstract}
Abstrak. Tembikar dapat digunakan untuk mengetahui tingkat kepandaian teknologis dan aktivitas masyarakat pada masa lalu. Guna mengetahui hal tersebut, maka perlu diketahui tingkat teknologi tembikar, bentuk, dan motif hias, serta kaitan antara fungsi tembikar dan fungsi situs pada masa lalu. Ragam tembikar ini diharapkan dapat digunakan untuk mengetahui aktifitas yang pernah terjadi di lokasi ini. Permasalahan tersebut dijawab dengan menggunakan teknik pengamatan berdasarkan variabel jejak buat, warna bagian permukaan dan inti tembikar, motif hias dan teknik hias. Selain itu, juga dilakukan penggambaran dengan teknik mirror untuk bagian tepian tembikar. Gambaran ini dapat dijadikan sebagai tambahan informasi perkembangan sejarah kebudayaan di Sintang dan sekitarnya. Tembikar Istana Almukarramah yang terdiri dari periuk, mangkuk, kendi, dan tembikar berbentuk persegi, dibentuk dengan tangan, alat, dan gabungan kedua teknik tersebut. Tidak semua bahan tanah liat dipilih dengan baik. Rata-rata tembikar dibakar pada suhu yang rendah sampai sedang, meskipun terdapat beberapa yang dibakar pada suhu tinggi. Motif hias dan teknik yang digunakan sangat bervariasi. Pada umumnya motif hias yang ditemukan berupa garis horisontal dan vertikal, namun terdapat juga motif hias berupa bulan sabit, duri ikan, dan bentuk persegi. Tembikar Istana Almukarramah digunakan sebagai peralatan sehari-hari dan alat upacara. Asumsi ini didasarkan pada fungsi lokasi Istana Almukarrammah sebelum tahun 1932. Pada masa tersebut lokasi ini dimanfaatkan sebagai pemukiman yang lingkungannya berupa semak belukar dan ditumbuhi pohon sagu. Beliung persegi tampaknya digunakan sebagai alat untuk eksploitasi sagu, sedangkan tembikar digunakan sebagai peralatan sehari-hari mereka. Fungsi tembikar sebagai alat upacara didasarkan pada banyaknya temuan tembikar di sekitar Batu Kundur.
\end{abstract}

Kata Kunci: teknologi, bentuk, fungsi, motif hias, tembikar, Sintang

\begin{abstract}
Pottery can be used to determine the level of technological skill and community activities in the past. Therefore, it is necessary to determine the level of technology of pottery, shapes and motifs, and the link between pottery function and site functionality in the past. Variety of pottery is expected to be used to determine the activities that have occurred at the site. This image can be used as additional information on the cultural history of Sintang and its surroundings. The potteries are consisting of pots, bowls, jugs, and a square-shaped. It were molded by hand, tools, and combined of these two techniques. The clay material is not all well chosen. Average pottery burned at low to moderate temperatures, although some of them were burned at high temperatures. The pottery decorations and techniques are widely varied. In general, motifs are found in the form of horizontal and vertical lines, but there is also a motif in the form of a crescent moon, fish spines, and a square shape. Pottery was used as everyday equipment and tool ceremony. This assumption is based on the function of palace location before 1932. At that time, the area was shrub land as habitat of sago palms. Hand axe seems to be used as a tool for exploitation of sago, while pottery used as their everyday equipment. The pottery function supposed to be a ceremonial tool is based on its location around Batu Kundur.
\end{abstract}

Keywords: Technology, form, function, decoration, pottery, Sintang 


\section{PENDAHULUAN}

Material Culture atau budaya materi merupakan bagian terpenting dalam ilmu arkeologi. Salah satu budaya materi yang paling banyak ditemukan dalam setiap ekskavasi adalah tembikar. Tembikar dapat merekonstruksi sejarah kebudayaan masa lalu tata cara hidup manusia, dan pada tingkat yang lebih tinggi, dapat digunakan untuk menyusun sejarah budaya masa lalu (Wahyudi 2012: 2). Tembikar berkembang pada masa neolitik sekitar 2500 sampai 1500 Sebelum Masehi (SM). Berdasarkan hasil analisis carbon dating, beberapa tembikar tertua di Indonesia antara lain ditemukan di Leang Tuwo Mane'e, Leang Burung, Ulu Leang, dan Gua Galo (Noerwidi 2007: 199). Tembikar sering diasosiasikan dengan paket budaya neolitik yang muncul bersamaan dengan proses migrasi komunitas Austronesia awal dari Taiwan yang menyebar ke wilayah Asia Tenggara, hingga Madagaskar dan Polynesia. Pada masa neolitik di Indonesia berkembang dua tradisi tembikar yaitu, Sa Hyunh-Kalanay dan Bau Malayu. Tradisi Sa Hyunh-Kalanay adalah tradisi tembikar yang berasal dari Vietnam dan Filipina, sedangkan Bau Malayu berasal dari Cina bagian selatan. Selain itu, di Indonesia juga ditemukan tembikar lapita yang berasal dari kepulauan pasifik dan arikamedu yang berasal dari India.

Penelitian terhadap aspek-aspek tembikar yang ditemukan di Indonesia sudah sering kali dilakukan. Hampir semua penelitian tembikar dilakukan di situs prasejarah dan situs HinduBuddha. Penelitian terhadap tembikar yang ditemukan di situs Islam dan kolonial masih sangat jarang dilakukan. Di Kalimantan, selain ditemukan di situs masa prasejarah, tembikar juga di temukan di situs Islam. Situs-situs tersebut antara lain Makam Sultan Suriansyah di Kuin, Banjarmasin dan Istana Almukarrammah di Sintang. Meskipun banyak tembikar ditemukan di situs Islam, tembikar yang ditemukan tidak serta merta berasal dari masa yang sama dengan usia situs tersebut, karena terdapat kemungkinan adanya penghunian berlanjut pada lokasi tersebut. Oleh karena itu, untuk mengetahui keterkaitan antara tembikar dan lokasi ditemukannya perlu dilakukan analisis carbon dating.

Pada tahun 1996, Balai Arkeologi Jawa Barat melakukan ekskavasi di sekitar Masjid Jami Sultan Nata dan Museum Dara Juanti atau Istana Almukarrammah Sintang. Penggalian ini dilakukan karena terdapat laporan penemuan beliung persegi pada saat pemugaran Masjid Jami Sultan Nata (Yondri 2000:10-31). Hasil dari penelitian ini berupa batu-batu dengan sisa pengasahan, fragmen keramik, fragmen tembikar, manik-manik, dan gelang emas (Yondri 2000:10-31). Berdasarkan hasil ekskavasi ini terdapat fakta yang sangat unik. Beliung persegi dan batu yang diasah atau diupam adalah artefak yang sering ditemukan pada situs prasejarah. Namun di situs Istana Almukarramah, beliung persegi dan batu yang diasah ditemukan di situs Islam.

Penelitian juga dilakukan oleh Balai Arkeologi Kalimantan Selatan pada tahun 2012 dengan melakukan survei dan ekskavasi di sekitar Istana Almukarrammah, Sintang. Survei permukaan dilakukan untuk mengetahui kandungan data arkeologi yang ada di sekitar Istana Almukarramah. Hasilnya ditemukan fragmen tembikar dan keramik di permukaan tanah Istana Almukarramah, meskipun kuantitasnya tidak banyak. Ekskavasi dilakukan dengan membuka empat kotak, dua di bagian depan istana dan dua lainnya di bagian belakang istana. Data arkeologi yang ditemukan dalam ekskavasi lebih beragam dibandingkan hasil survei permukaan. Hasil dari ekskavasi adalah fragmen tembikar, fragmen stoneware, fragmen keramik, batu alam yang telah diupam, paku, mata uang, dan manik-manik. Dalam penggalian ini data yang paling banyak ditemukan adalah fragmen tembikar atau earthenware.

Tembikar pada umumnya memiliki berbagai macam kualitas. Hal ini sangat tergantung pada tingkat suhu pada proses pembakaran, temper, dan jenis tanah liat (Orton dkk. 1993: 67). Tingkat suhu pembakaran pada dasarnya akan menghasilkan warna yang berbeda. Perbedaan suhu pembakaran dan kondisi pembakaran tidak hanya berpengaruh pada bagian permukaan saja, namun juga berpengaruh pada bagian inti dan margin. Suhu pembakaran juga sangat 
berpengaruh pada tingkat kekuatan tembikar. Temper adalah bahan lain yang dicampurkan ke dalam tanah liat. Tujuan pencampuran tanah liat dengan temper adalah menjaga kelembaban tanah liat pada saat dikeringkan sebelum proses pembakaran. Terdapat berbagai macam temper yang telah digunakan dalam pembuatan tembikar. Di antara temper yang paling sering digunakan adalah sekam padi, pasir, fragmen tembikar, dan cangkang kerang. Terakhir adalah tanah liat yang merupakan bahan baku utama tembikar. Pemilihan jenis tanah liat sangat berpengaruh terhadap hasil akhir tembikar.

Keseluruhan proses pemilihan tanah liat, pembentukan tanah liat, pengeringan, dan pembakaran akan menghasilkan sebuah tembikar yang pada akhirnya akan memiliki fungsi yang berbeda-beda. Menurut Solheim, tembikar dapat berfungsi sebagai peralatan sehari-hari misalnya untuk memasak, sebagai wadah air maupun sebagai wadah makanan, dan sebagai peralatan untuk upacara (Solheim 1965: 254-273). Orton dkk mengkategorikan fungsi tembikar sebagai wadah, sarana memproses, dan sarana mentransfer (Orton dkk. 1993: 217). Tembikar juga dapat digunakan untuk menggambarkan status sosial seseorang yang memiliki tembikar dengan kualitas dan motif hias tertentu (Orton dkk. 1993: 76).

Berdasarkan penjelasan singkat tersebut, dapat disimpulkan bahwa mempelajari tembikar dapat digunakan untuk mengetahui tingkat kepandaian teknologis dan aktivitas masyarakat masa lalu. Berdasarkan hal ini, maka permasalahan yang diajukan adalah.

1. Bagaimanakah teknologi pembuatan tembikar yang ditemukan di Istana Almukarrammah?

2. Bagaimanakah bentuk dan motif hias tembikar?

3. Bagaimanakah kaitan antara fungsi tembikar dan lingkungan situs pada masa lalu?

Makalah ini bertujuan untuk memberikan gambaran mengenai ragam tembikar yang ada di sekitar Istana Almukarrammah, Sintang. Ragam tembikar diharapkan dapat digunakan untuk mengetahui aktivitas yang pernah terjadi di lokasi ini. Gambaran tersebut dapat dijadikan sebagai tambahan informasi perkembangan sejarah kebudayaan di Sintang dan sekitarnya.

Teknologi pembuatan tembikar dititikberatkan pada teknik pembentukan dan pembakaran. Pembakaran terkait dengan kondisi dan suhu. Suhu akan dikategorikan ke dalam ukuran rendah, sedang, dan tinggi. Selain itu, juga akan dikaitkan dengan waktu pembakaran tembikar yang akan dikategorikan dalam sebentar dan lama.

Bentuk akan diperoleh dari bagian tepian tembikar yang telah direkonstruksi dengan bantuan vessel diameter. Selain dengan bantuan vessel diameter beberapa tembikar tidak akan digambar karena sudah diketahui bentuknya. Motif hias akan dideskripsikan berdasarkan teknik pembuatan dan bentuk motif hias yang ditemukan. Permasalahan fungsi tembikar akan diperoleh berdasarkan bentuk, jejak pakai, dan lokasi temuan tembikar. Selanjutnya, fungsi tembikar akan dibandingkan dengan kesejarahan lokasi situs.

Tembikar merupakan benda-benda tanah liat yang dibentuk wadah dan dibakar dengan suhu sekitar $800-1200^{\circ} \mathrm{C}$ (Wahyudi 2012: 1; Rice 1987: 5). Pengertian tembikar lebih mengacu pada bahan dan suhu pembakaran, sedangkan gerabah lebih mengacu pada jenis atau bentuk benda pecah belah seperti mangkuk dan piring tanpa melihat bahan pembuatnya (Wahyudi 2012: 2). Berdasarkan pendapat tersebut, pengertian tembikar terbatas pada tanah yang dibentuk menjadi wadah kemudian dibakar. Tanah liat yang dibentuk menjadi benda bukan wadah seperti bata, patung terakota, dan genteng tidak dapat disebut sebagai tembikar.

Teknik pembentukan tembikar dapat dibagi menjadi dua, yaitu pembentukan dengan tangan dan pembentukan dengan bantuan alat. Teknik pembentukan tembikar dengan tangan antara lain adalah teknik pijat, teknik spiral, teknik cincin, dan teknik lempeng (Simanjuntak dkk. 2008: 60). Teknik pijat akan menghasilkan jejak jari tangan pada permukaan bagian dalam. Teknik spiral dan teknik cincin pada dasarnya hampir sama. Tanah liat yang akan digunakan dibentuk menyerupai pipa. Pada teknik spiral tanah liat akan diputar terus-menerus sehingga saling bertumpuk. 
Posisi tumpukan biasanya miring ke atas. Pada teknik cincin tanah liat yang telah dibentuk menyerupai pipa disusun melingkar satu persatu. Jejak buat yang tampak pada teknik spiral dan cincin adalah cekungan cekungan memanjang dan melingkar ke atas ataupun melingkar lurus. Cekungan ini adalah bagian sambungan antartumpukan. Teknik lempeng juga akan menghasilkan jejak buat sama dengan teknik cincin, namun bentuknya kurang membulat.

Pembentukan tembikar dengan bantuan alat terdiri dari tatap pelandas dan roda putar. Khusus untuk roda putar biasanya dibagi menjadi dua, yaitu roda putar lambat dan roda putar cepat. Teknik tatap landas akan menghasilkan permukaan luar yang tidak rata. Pada bagian permukaan dalam akan terbentuk cekungancekungan dengan ukuran agak besar. Pada umumnya, alat yang digunakan sebagai tatap permukaan bagian luar memiliki motif pada bagian permukaannya. Adanya motif pada permukaan alat tatap ini menyebabkan permukaan tembikar langsung berhias ketika dibentuk. Biasanya motif hias yang ada saling bertumpuk. Teknik roda putar lambat dan cepat akan menghasilkan striasi. Striasi adalah jejak-jejak garis pada permukaan luar tembikar. Striasi yang dihasilkan oleh roda putar cepat lebih lurus dan rapi jika dibandingkan dengan striasi roda putar lambat. Terdapat juga teknik pembentukan tembikar yang menggabungkan antara tangan dan alat ataupun alat dan alat.

Menurut Orton, berdasarkan proses pembakaran, warna tembikar dapat dikelompokkan ke dalam lima bagian, yaitu:

1. Inti atau core

a. Inti berwarna hitam atau abu-abu gelap disebabkan oleh pembakaran yang kurang sempurna. Warna hitam disebabkan karena adanya karbon dalam material organik yang terbakar.

b. Inti abu-abu disebabkan karena karbon dalam material organik.

c. Inti coklat dan merah disebabkan oksigen teroksidasi dengan baik dengan pembakaran tinggi.

2. Margin atau area di antara permukaan dan inti a. Bila tidak terdapat perbedaan antara margin dan inti mengindikasikan pembakaran sempurna dalam durasi yang cukup lama.

b. Bila terdapat perbedaan warna mengindikasikan pembakaran rendah dengan durasi yang tidak lama.

3. Margin luar dan margin dalam

Margin luar dan margin dalam memiliki warna yang berbeda disebabkan karena ketika pembakaran, bagian tepian tembikar dalam kondisi tertutup oleh permukaan tanah atau tembikar lainnya.

4. Permukaan luar

Perbedaan warna yang mencolok antara margin dan permukaan mengindikasikan pembakaran rendah atau juga disebabkan karena tungku pembakaran terbuka ketika tembikar masih dalam kondisi panas. Hal ini menyebabkan oksigen masuk ke dalam tungku dan menyebabkan permukaan tembikar berwana coklat ataupun merah (Orton dkk. 1993: 68-69).

Berbeda dengan Orton, Rice (1987: 345) membuat sebuah panduan hubungan warna tembikar dan kondisi pembakaran seperti dalam tabel 1.

\section{Pendapat Orton dan Rice Akan Dijadikan Variabel dalam Menjawab Permasalahan Pertama}

Belum terdapat standar baku dalam menyebut bentuk motif hias. Masing-masing peneliti atau pemerhati tembikar akan menyebut nama motif hias sesuai bentuknya. Namun terdapat juga nama yang umum digunakan seperti geometris, garis, jaring atau jala, dan floral. Pengamatan terhadap teknik hias dapat dilihat dari jejak-jejak yang ditinggalkan. Teknik yang digunakan dalam membuat motif hias adalah penggarukan, penggaluran, mengiris, pengukiran, tera atau cap, pemangkasan, tera rol, dan rolet (Orton dkk. 1993: 86)

Dalam rangka analisis fungsi, Clive Orton, dkk. mengatakan bahwa fungsi tembikar tidak bisa dilihat dari bentuknya saja, fungsi tembikar 
Tabel 1. Hubungan antara warna dan kondisi pembakaran

\begin{tabular}{|c|c|c|c|}
\hline \multicolumn{2}{|c|}{ Warna } & \multirow{2}{*}{$\begin{array}{l}\text { Kemungkinan } \\
\text { Pembakaran }\end{array}$} & \multirow[t]{2}{*}{ Keterangan } \\
\hline Permukaan & Inti/core & & \\
\hline \multicolumn{2}{|c|}{$\begin{array}{l}\text { Warna bersih; warna sama } \\
\text { pada seluruh bagian }\end{array}$} & Oksidasi Sempurna & $\begin{array}{l}\text { Tidak ada bukti kandungan karbon pada tanah } \\
\text { liat, perkembangan warna tergantung pada } \\
\text { keberadaan besi }\end{array}$ \\
\hline Coklat & Coklat & $\begin{array}{l}\text { Oksidasi sedang } \\
\text { menuju sempurna }\end{array}$ & $\begin{array}{l}\text { Kemungkinan diasapi dengan suhu rendah; } \\
\text { warna tergantung pada keberadaan besi } \\
\text { dalam bentuk feriic; pembakaran ulang dapat } \\
\text { mencerahkan warna }\end{array}$ \\
\hline $\begin{array}{|lr|}\text { Abu } & \text { bersih } \\
\text { atau } & \text { abu } \\
\text { muda } & \\
\end{array}$ & $\begin{array}{lr}\text { Abu terang } \\
\text { sampai abu } \\
\text { tua }\end{array}$ & Oksidasi sedang & $\begin{array}{l}\text { Kandungan karbon dalam tanah liat tidak } \\
\text { cukup terbakar sehingga tidak dapat } \\
\text { menoksidasi organik dan memunculkan warna }\end{array}$ \\
\hline Abu muda & Abu muda & Oksidasi sedang & - \\
\hline $\begin{array}{l}\text { Abu tua atau } \\
\text { hitam }\end{array}$ & $\begin{array}{l}\text { Abu tua atau } \\
\text { hitam }\end{array}$ & $\begin{array}{l}\text { Oksidasi kurang atau } \\
\text { terlalu berasap }\end{array}$ & Mengandung karbon yang sangat tinggi atau \\
\hline $\begin{array}{l}\text { Abu tua atau } \\
\text { hitam }\end{array}$ & Abu muda & $\begin{array}{l}\text { Pembakaran terlalu } \\
\text { berasap }\end{array}$ & $\begin{array}{l}\text { Karbon terendapkan pada permukaan selama } \\
\text { dan sesudah pembakaran. Inti berwarna muda } \\
\text { menunjukan tanah liat bukan organik }\end{array}$ \\
\hline Putih & Puth & Tidak menentu & $\begin{array}{l}\text { Kemungkinan tanah liat kurang besi dan } \\
\text { organik }\end{array}$ \\
\hline
\end{tabular}

Sumber: Rice 1987: 345

ditentukan oleh temuan lain yang menyertainya (Orton dkk. 1993: 28-29). Oleh sebab itu, untuk melakukan analisis fungsi tembikar maka perlu diperhatikan konteks lokasi temuan tembikar dengan kondisi sekitarnya.

\section{METODE}

Upaya menjawab permasalahan dalam tulisan ini, maka diperlukan langkah-langkah kerja yang dibagi menjadi dua tahapan. Tahap pertama adalah pengumpulan data. Data yang dikumpulkan terdiri dari data pustaka dan hasil test pit. Pengumpulan data pustaka dilakukan pada saat prapenelitan lapangan dan paska penelitian lapangan. Data pustaka yang dikumpulkan pada saat prapenelitian adalah informasi terkait kondisi lingkungan, kepurbakalaan, sejarah, dan hubungan situs dengan situs yang lainnya. Data pustaka yang membahas tentang tembikar akan dikumpulkan setelah kegiatan penelitian lapangan. Kegiatan test pit akan diawali dengan survei permukaan. Survei permukaan dilakukan untuk mengetahui lokasi yang memiliki kandungan data arkeologi paling banyak. Dalam kegiatan survei permukaan ini, data arkeologi tidak diambil. Temuan data permukaan hanya akan dijadikan pertimbangan dalam pemilihan lokasi test pit. Test pit akan menggunakan sistem spit. Satu spit memiliki kedalaman $20 \mathrm{~cm}$.

Tahap selanjutnya adalah klasifikasi data artefaktual. Klasifikasi dibagi menjadi dua, yaitu klasifikasi umum dan klasifikasi khusus. Klasifikasi umum adalah pembagian data artefaktual hasil test pit berdasarkan jenis bahannya. Klasifikasi khusus hanya akan dilakukan pada fragmen tembikar. Fragmen tembikar akan diklasifikasikan berdasarkan posisi aslinya, yaitu, kaki, dasar, badan, karinasi, cucuk, leher, tepian, tutup, dan pegangan. Dalam klasifikasi ini, fragmen tembikar tak berhias dan berhias akan langsung dipisahkan.

Teknik sampling akan dilakukan untuk tahapan analisis data. Dari hasil klasifikasi khusus, akan diambil sampel yang dianggap mewakili populasi teknik pembuatan tembikar, warna permukaan, inti dan margin tembikar, bagian tepian yang dapat direkonstruksi bentuknya, motif hias, dan jejak pakai. Keseluruhan tembikar yang dipilih sebagai sampel inilah yang akan dianalisis secara mendalam untuk menjawab permasalahan.

Analisis terhadap teknologi pembuatan tembikar hanya akan dilakukan secara manual. Adanya keterbatasan alat menyebabkan analisis ini hanya akan dilakukan dengan pengamatan mata terhadap jejak buat dan warna tembikar pada bagian inti, margin, permukaan luar, dan permukaan dalam tembikar. Analisis terhadap 
bentuk tembikar hanya akan dilakukan pada bagian tepian. Rekonstruksi tembikar dilakukan dengan cara mengukur bagian tepian dengan bantuan alat yang dinamakan vessel diameter. Hasil pengukuran ini akan diketahui diameter bagian tepian tembikar. Langkah selanjutnya adalah membuat gambar bagian tepian tembikar. Gambar tepian ini akan dibuat pada selembar kertas. Setelah gambar tepian selesai maka akan dilakukan teknik mirror, sehingga akan tergambar dua tepian tembikar yang saling berhadapan. Jarak antara tepian tembikar pertama dan kedua diperoleh dari hasil pengukuran dengan vessel diameter.

Dari hasil rekonstruksi ini akan diperoleh bentuk asli dari tembikar. Hasil rekonstruksi ini akan digunakan untuk memperkirakan fungsi dari tembikar. Selain berdasarkan bentuk, fungsi tembikar juga akan diamati dari bagian permukaan luar dan bagian dalam tembikar. Pengamatan ini akan dititkberatkan pada jejak pakai. Mengingat bahwa penelitian ini tidak didukung oleh analisis laboratorium, maka jejak pakai yang diamati adalah jejak pembakaran. Keseluruhan alur kerja dalam penyusunan karya tulis ini dapat dilihat pada gambar 1 .

\section{HASIL DAN PEMBAHASAN}

\section{Survei dan Ekskavasi}

Istana Almukarrammah terletak tepat di depan pertemuan Sungai Melawi dan Sungai Kapuas (lihat gambar 2). Di sekitar Istana Almukarrammah terdapat parit yang mengelilingi. Istana Almukarrammah terletak pada permukaan tanah yang datar. Pada bagian barat istana terdapat masjid istana yang bernama Masjid Jami Sultan Nata. Pada bagian belakang atau timur istana terdapat kompleks makam kerajaan.

Tahap awal penelitian situs Istana Almukarrammah dilakukan dengan survei permukaan. Permukaan tanah di sekitar Istana Almukarramah diamati dari jarak dekat dengan tujuan mencari data arkeologi yang ada di permukaannya. Hasil survei permukaan adalah temuan berupa tonggak-tonggak dari kayu belian yang berjumlah tujuh buah di halaman belakang

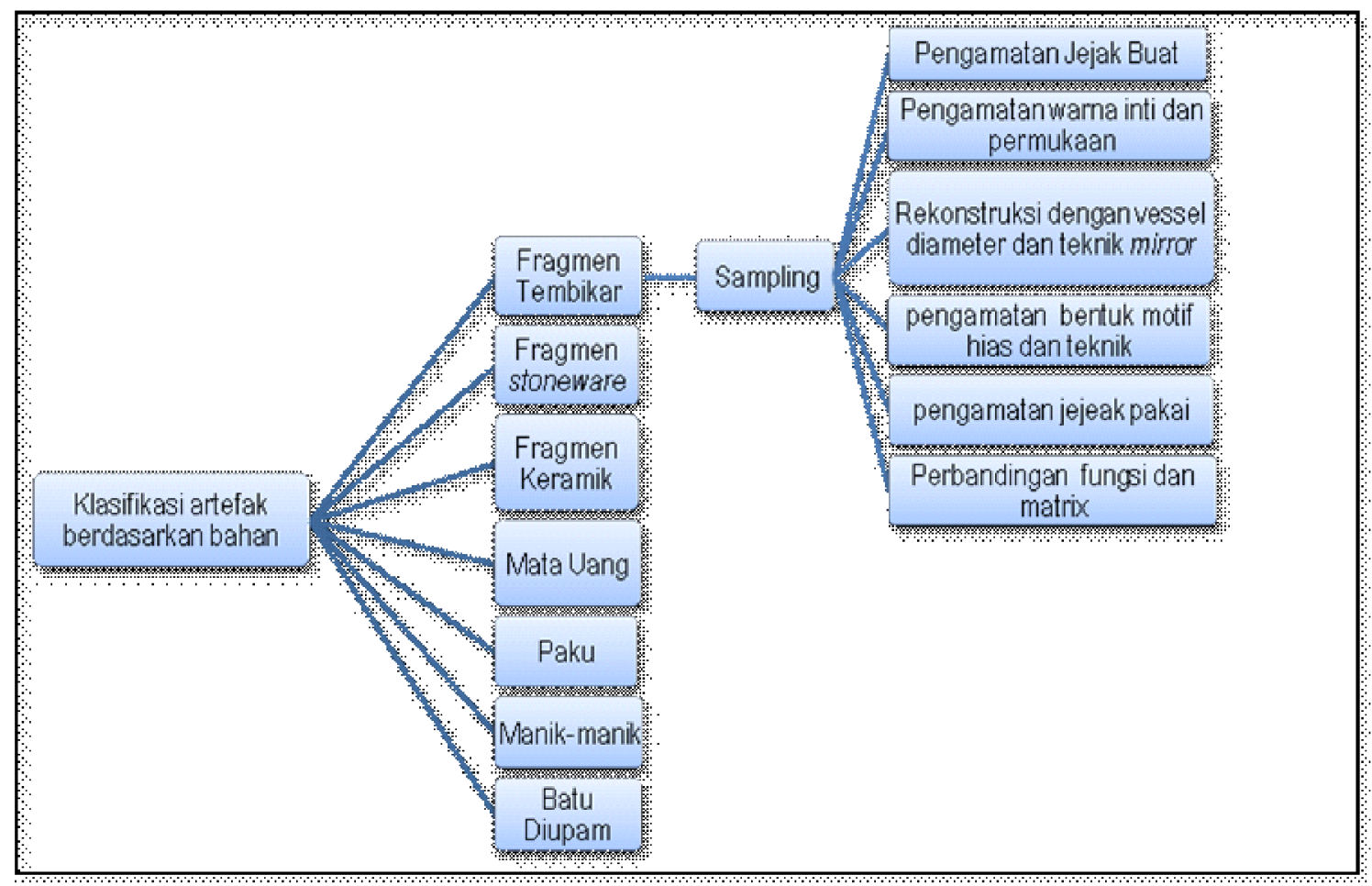

sumber: rangkuman metode penelitian

Gambar 1. Bagan alur kerja penelitian. 
Istana Almukarramah. Satu tiang tonggak kayu belian telah diangkat ke permukaan tanah. Pada salah satu ujung kayu belian yang telah diangkat terdapat lubang berbentuk persegi panjang yang digunakan untuk memasukkan kayu sebagai kalang sunduk. Selain itu, di halaman depan istana terdapat sebuah batu yang oleh masyarakat Sintang dikenal dengan sebutan Batu Kunduratau batu labu (lihat gambar 3). Terdapat juga temuan fragmen tembikar, stoneware, dan keramik di seluruh halaman Istana Almukarrammah.

Hasil survei permukaan ini dijadikan pertimbangan utama dalam rangka memilih lokasi kotak ekskavasi. Kotak ekskavasi pertama dibuka di lokasi Batu Kundur. Kotak ini dinamakan TP 1 atau test pit 1. Lebar kotak dan arah hadap kotak menyesuaikan fondasi cungkup Batu Kundur. Hasil dari test pit ini adalah fragmen tembikar, fragmen stoneware, fragmen keramik asing, fragmen kaca, batu yang diupam, mata uang, paku, dan fragmen arang. Penggalian ini dilakukan hingga spit 4 atau $80 \mathrm{~cm}$ dari fondasi.
Ekskavasi juga dilakukan di bagian belakang Istana Almukarrammah. Di lokasi ini dibuat dua kotak ekskavasi yang bernama U7T4 dan U6T6. Ukuran kedua kotak ekskavasi ini adalah $1 \times 2$ meter. Hasil dari ekskavasi pada kedua kotak ini adalah fragmen tembikar, fragmen stoneware, fragmen keramik, fragmen kaca, dan paku. Ekskavasi pada kotak U7T4 dihentikan pada spit 4 atau kedalaman $110 \mathrm{~cm}$. Dari kedalaman 110 $\mathrm{cm}$ ini, $30 \mathrm{~cm}$ terletak di permukaan tanah. Hal ini disebabkan karena pengukuran kedalaman dilakukan dari datum point sekunder yang terletak $30 \mathrm{~cm}$ di atas permukaan tanah kotak ekskavasi. Penggalian kotak U6T6 dihentikan pada spit 2 atau kedalaman $70 \mathrm{~cm}$ dari datum point sekunder.

Ekskavasi terakhir dilakukan di bagian depan istana yang berjarak 2 meter dari TP 1. Kotak ini diberi nama TP 2, yang berukuran $1 \times 1$ meter. Hasil dari ekskavasi TP 2 adalah fragmen tembikar, fragmen stoneware, fragmen keramik, fragmen kaca, mata uang, manik-manik, batu-bata, dan paku. Penggalian di TP 2 dihentikan pada

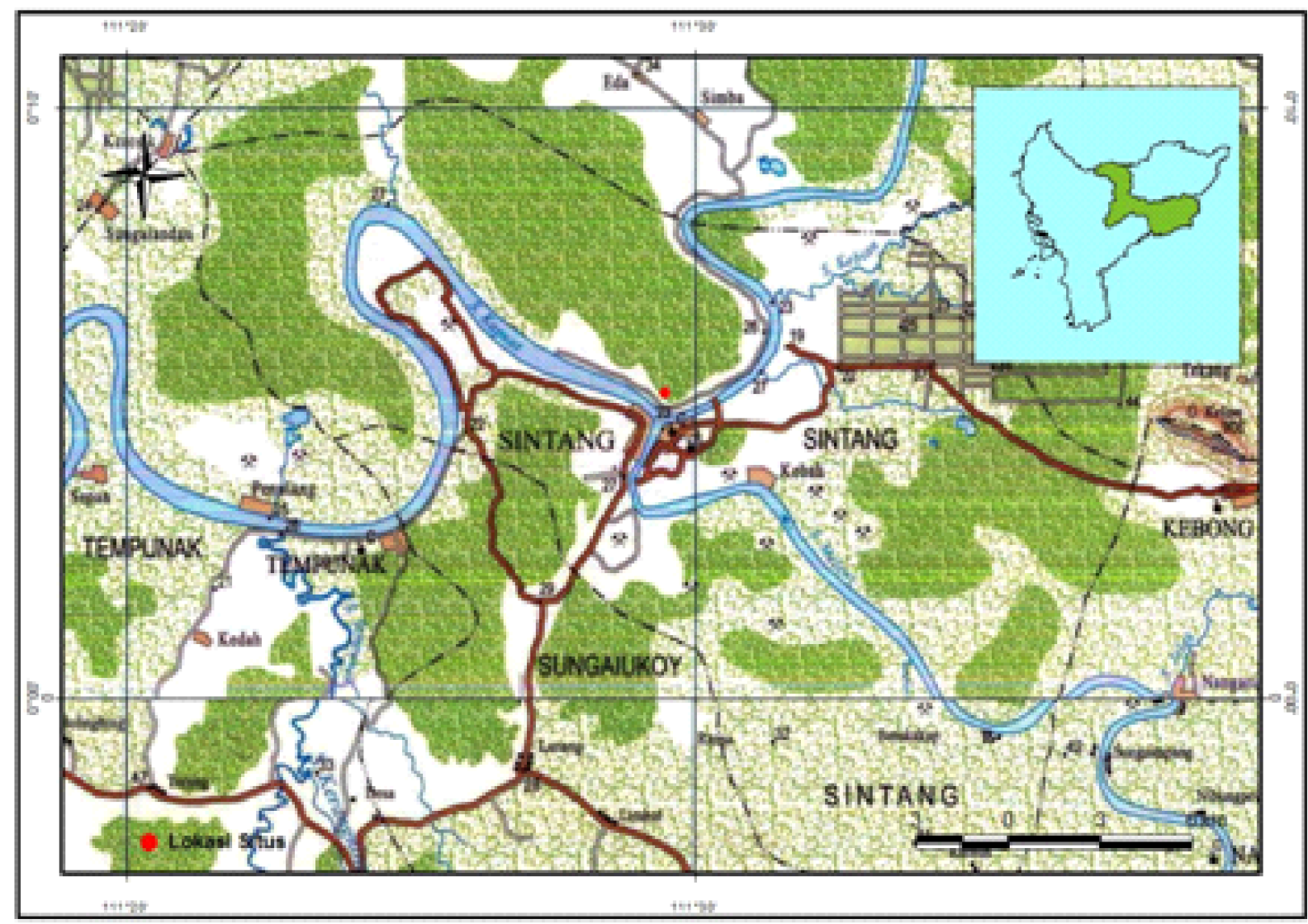

sumber: hasil pengolahan pribadi

Gambar 2. Lokasi Istana Almukarramah. 


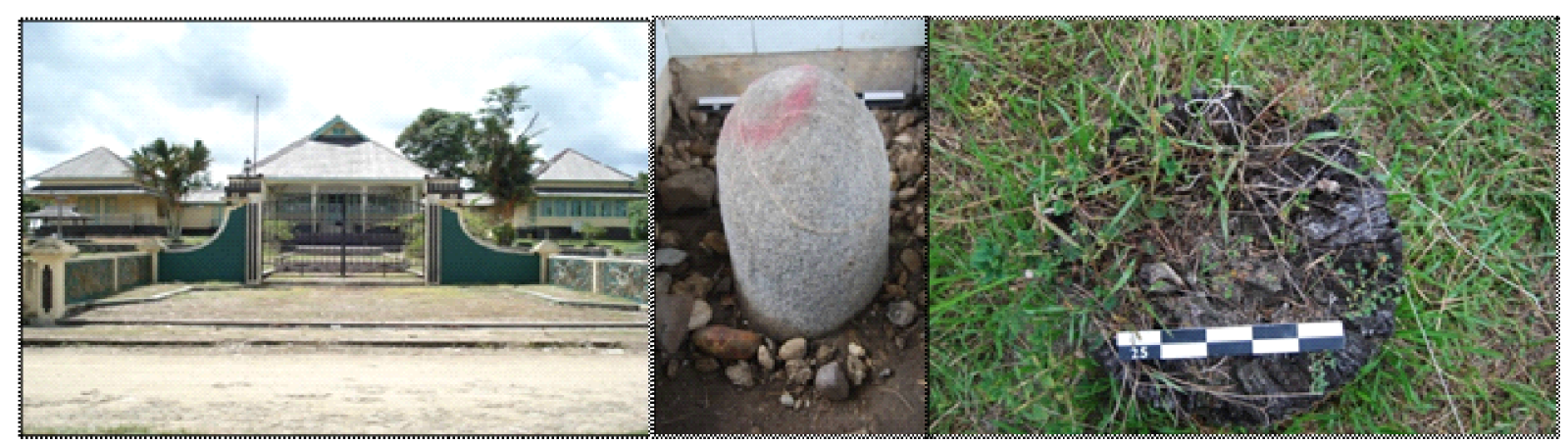

sumber: dok. Balai Arkeologi Kalimantan Selatan

Gambar 3. Istana Almukarrammah (kiri), Batu Kundur(tengah), Tonggak kayu belian (kanan)

spit 2 yang kedalamannya adalah $70 \mathrm{~cm}$ dari datum point sekunder.

Berdasarkan layer tanah, kepadatan tanah, dan konteks temuan pada keempat kotak ekskavasi yang telah digali, menunjukkan bahwa tiga buah kotak ekskavasi yaitu, TP 1, kotak U7T4, dan kotak U6T6 lapisan tanahnya telah teraduk. Lapisan tanah pada TP 2, masih relatif asli atau belum teraduk. Hal ini dibuktikan dari keadaan tanah yang sangat padat dan beberapa temuan data arkeologi masih dalam keadaan in situ. Hasil pengamatan ini juga didukung oleh informasi yang menyatakan bahwa, tanah di halaman belakang istana pada masa lalu sering digali untuk mencari emas. Tanah pada TP 1 merupakan tanah timbunan ketika cungkup Batu Kundur selesai dibuat.

\section{Analisis Tembikar}

Tahap pertama dalam analisis tembikar adalah mengetahui jumlah dan bagian-bagian dari fragmen tembikar. Hal ini disebabkan karena tembikar yang ditemukan hanya pecahan-pecahan kecil saja. Dalam analisis, tembikar dibagi menjadi 12 bagian, yaitu pegangan tutup, tutup, tepian, leher, cucuk, karinasi, badan, dasar, kaki, pegangan, dan kupingan. Jumlah masing-masing bagian yang ditemukan dapat dilihat pada tabel 2.

Dari jumlah tersebut, dapat diketahui bagianbagian tembikar yang ditemukan adalah pegangan tutup, tutup, tepian, leher, cucuk, karinasi, badan, dan dasar. Selain temuan bagian tembikar tersebut, juga terdapat dua tembikar yang memiliki bentuk persegi.Tembikar pertama merupakan bagian dasar.Tembikar ini berbentuk siku. Tembikar kedua adalah bagian tepian. Pada umumnya tepian yang ditemukan berbentuk melengkung, namun temuan tepian ini berbentuk lurus. Bagian yang tidak ditemukan adalah kaki, kupingan, dan pegangan.

Dari jumlah 1347 diambil sampel sebanyak 106 untuk dianalisis secara lebih mendalam. Seratus enam tembikar yang dijadikan sampel terdiri dari bagian dasar, badan, cucuk, karinasi, dasar, tepian, tutup, dan pegangan tutup. Tutup dan pegangan tutup dipisahkan karena temuan bagian ini tidak menyatu. Sampel tembikar inilah yang dianggap mewakili keseluruhan populasi.

Analisis teknologi pembentukan tembikar dilakukan dengan teknik pengamatan jejak pakai. Beberapa dari tembikar yang dijadikan sampel tidak memperlihatkan jejak buat, karena bentuknya terlalu kecil. Teknik pembentukan tembikar yang pertama adalah spiral. Teknik spiral digunakan untuk membuat bagian tutup. Pada permukaan bagian dalam tembikar yang dibuat dengan teknik spiral masih menunjukkan bagian berlubang memanjang dengan posisi miring ke atas. Teknik yang kedua adalah teknik tekan atau pijit. Teknik pijit digunakan untuk membuat bagian pegangan tutup dan bagian badan tembikar. Pegangan tutup ini disambungkan ke bagian tutup, sehingga untuk membuat bagian tutup dengan pegangannya digunakan dua teknik, yaitu teknik spiral dan teknik tekan atau pijat. Bagian badan tembikar yang dibuat dengan menggunakan teknik tekan atau pijat menunjukkan jejak jari tangan yang berbentuk cekung dengan interval rapat pada pemukaan bagian dalam tembikar. 
Teknik pembentukan selanjutnya adalah pembentukan tembikar dengan bantuan alat. Alat yang digunakan dalam pembentukan tembikar adalah tatap landas dan roda putar. Khusus roda putar akan dibagi menjadi dua, yaitu roda putar lambat dan roda putar cepat. Penggunaan alat tatap pelandas tampak pada beberapa tembikar bagian badan. Jejak buat tampak pada permukaan bagian dalam yang tidak rata dan cenderung cekung dengan ukuran besar dengan interval cekungan tidak teratur. Motif pada permukaan alat tatap ini sekaligus akan meninggalkan jejak hias pada permukaan tembikar. Tembikar dari situs Istana Almukarrammah tampaknya juga dibuat dengan teknik roda putar lambat dan roda putar cepat. Hal ini tampak pada bagian permukaan depan badan tembikar yang memiliki jejak striasi. Jejak roda putar lambat tampak garis-garis yang tidak rapi dan terkadang terputus, sedangkan jejak roda putar cepat adalah striasi yang lurus dan rapi.

Tembikar yang ditemukan di situs Istana Almukarrammah juga dibentuk dengan teknik gabungan antara tekan atau pijit dengan roda putar cepat, tatap pelandas dengan roda putar lambat maupun roda putar cepat. Jejak buat pada tembikar yang dibentuk dengan teknik gabungan tampak pada permukaan bagian luar dan dalam tembikar. Klasifikasi teknik pembentukan tembikar dapat dilihat pada tabel 3 .

Teknologi pembuatan tembikar selanjutnya terkait dengan suhu dan kondisi pembakaran. Suhu dan kondisi pembakaran ini tampak pada warna yang ada pada bagian inti, margin luar, margin dalam, permukaan luar, dan permukaan dalam. Hasil pengamatan menunjukkan tidak adanya perbedaan warna antara bagian inti dan margin tembikar sehingga, dalam analisis ini, margin tidak akan disebutkan warnanya. Berdasarkan variabel yang dibuat oleh Orton, kesamaan warna antara inti dan margin menunjukkan bahwa pembakaran sempurna dalam waktu yang lama. Namun demikian, hal ini masih harus dilihat warna bagian permukaan luar dan dalam tembikar.

Berdasarkan pengamatan, warna bagian inti, permukaan luar, dan permukaan dalam tembikar yang ditemukan di Istana Almukarrammah adalah sebagai berikut.

1. Merah/Merah/Merah (M/M/M): warna yang sama pada seluruh bagian tembikar menunjukkan bahwa oksidasi sempurna dengan suhu pembakaran yang tinggi.

2. Merah/Abu tua/Abu muda (M/At/Am): warna merah pada permukaan dan warna abu tua pada bagian margin dan inti disebabkan karena suhu pembakaran rendah atau tungku terbuka ketika tembikar masih dalam kondisi panas. Terbukanya tungku menyebabkan oksigen masuk ke dalam tungku. Inti berwarna abu tua memiliki kandungan karbon yang tinggi yang disebabkan material organik tidak terbakar sempurna.

3. Abu tua/Abu tua/Abu muda (At/At/Am): Inti berwarna abu tua memiliki kandungan karbon yang tinggi yang disebabkan material organik tidak terbakar sempurna. Warna abu tua pada permukaan kemungkinan disebabkan karena asap pembakaran yang tebal.

4. Putih/Abu tua/Putih (P/Ab/P): warna putih pada permukaan tembikar mungkin disebabkan oleh tanah liat kurang mengandung besi dan organik. Inti berwarna abu tua memiliki kandungan karbon yang tinggi yang disebabkan material organik tidak terbakar sempurna. Tembikar dengan warna permukaan putih paling banyak ditemukan.

5. Abu muda/Abu tua/Abu muda (Am/At/Am): oksidasi kurang sempurna, karbon dalam tanah liat tidak cukup terbakar.

6. Abu tua/Abu tua/Abu tua (At/At/At): tanah liat mengandung karbon sangat tinggi, pembakaran kurang atau asap pembakaran sangat tebal.

7. Abu kekuningan/Abu tua/Abu kekuningan (Ak/At/Ak)

8. Abu muda/Abu muda/Abu muda (Am/Am/ $A m)$ : warna yang sama pada seluruh bagian tembikar menujukkan oksidasi sempurna.

9. Putih/Putih/Putih (P/P/P): tanah liat kurang mengandung besi dan organik. 
10. Hitam/Merah/Abu kekuningan (H/Mt/Ak): Tanah liat memiliki kandungan karbon yang tinggi atau asap pembakaran yang tebal. Bagian inti berwarna merah merupakan hasil oksidasi sempurna.

11. Abu Kekuningan/Abu tua/Hitam: oksidasi kurang sempurna atau asap pembakaran terlalu tebal.

Bagian tembikar Istana Almukarrammah apabila diukur dengan skala munsel terdiri dari pingkish white (5YR 8/2), light gray (5YR 6/1), dark gray (5YR 4/1), white (10R 5/8), white (7,5YR 8/1), red (10R 5/8), black (7,5YR 2/1), dark reddish gray (10R 3/1), light red (10R $7 / 8)$, dusky red (10R 3/4), dan very pale brown (10YR 8/3).

Berdasarkan deskripsi warna bagian inti, permukaan luar, dan permukaan dalam tembikar tampak bahwa sebagian besar warna inti tembikar adalah abu tua kemudian merah, putih, dan abu muda. Warna inti abu tua menunjukkan bahwa suhu pembakaran sangat kurang. Inti berwarna merah menunjukkan bahwa suhu pembakaran tinggi dan teroksidasi sempurna. Inti berwarna putih menunjukkan bahwa tanah liat kurang mengandung besi dan bahan organik, sedangkan inti berwarna abu muda oksidasi sedang. Berdasarkan warna-warna yang dihasilkan, tampaknya tembikar yang ditemukan di Istana Almukarrammah dibakar di tungku dan ruang terbuka.

Hal yang sangat mengejutkan adalah hadirnya tembikar dengan warna permukaan putih dan ada juga yang memiliki inti berwarna putih. Populasi tembikar yang ditemukan dengan warna putih sangat banyak. Apakah hal ini menunjukkan bahwa kurangnya pengetahuan akan sumber tanah liat atau memang ketiadaan bahan baku yang lebih baik. Hal ini tentu bertolak belakang dengan hadirnya

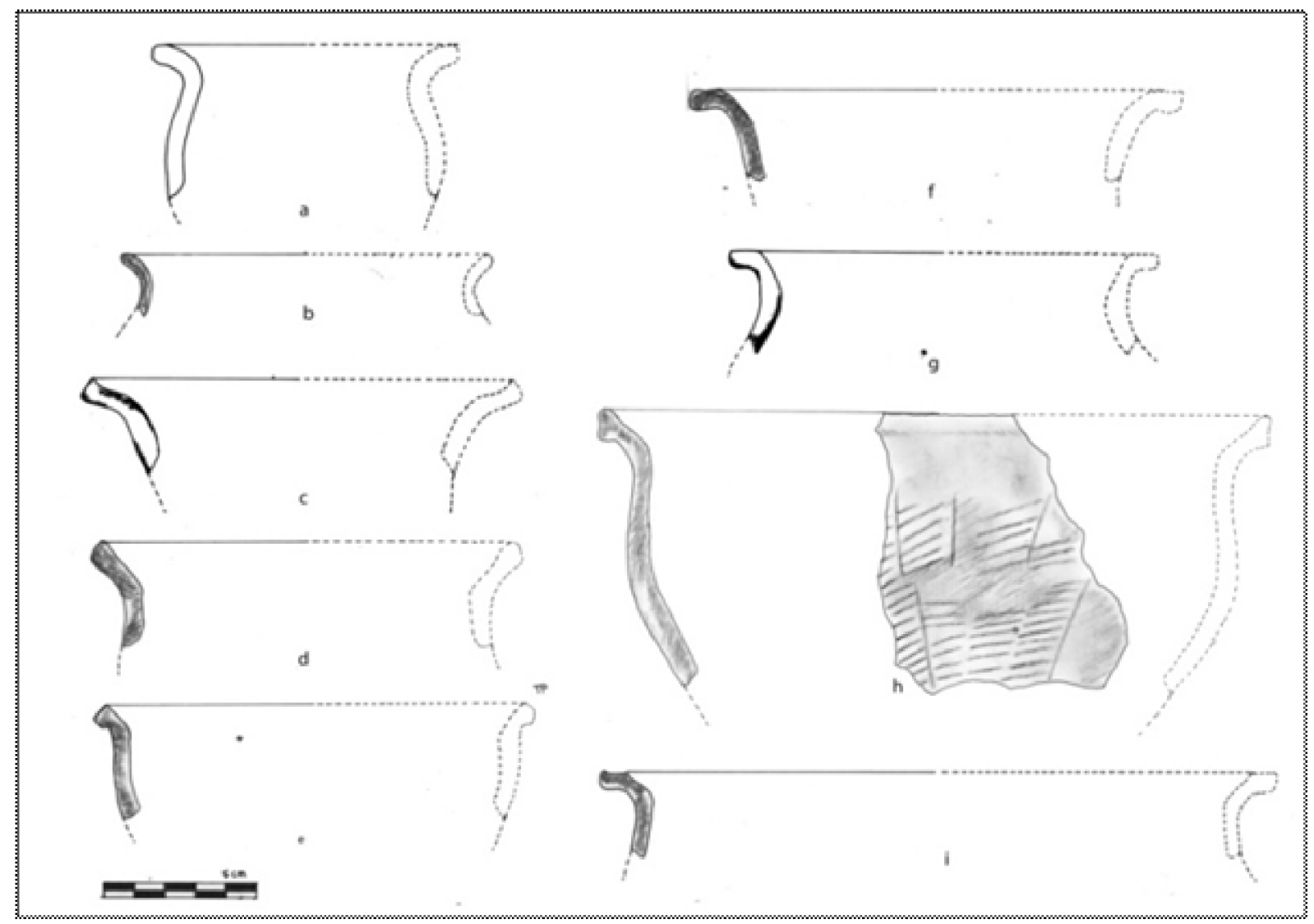

sumber: penggambaran pribadi

Gambar 4. Bentuk tembikar Istana Almukarrammah: a. periuk, b. periuk, c. mangkuk, d. periuk, e. mangkuk, f. mangkuk, g. periuk, h. mangkuk, i. periuk 
tembikar dengan warna-warna lain. Terdapat kemungkinan tembikar berwarna putih adalah tembikar lokal, meskipun kurang sempurna namun tetap digunakan, sedangkan tembikar berwarna lain merupakan produk luar wilayah. Tentu saja untuk pembuktian asumsi ini diperlukan analisis laboratorium dengan menguji kandungan tanah liat dari sekitar situs.

Merekonstruksi bentuk tembikar dapat dilakukan dengan melakukan pengukuran tepian dengan vessel diameter dan penggambaran. Dalam makalah ini, selain menggunakan teknik tersebut, terdapat beberapa tembikar yang tidak perlu digambar namun sudah dapat diketahui bentuknya. Hasil penggambaran bagian tepian tembikar menunjukkan bahwa sebagian besar tembikar berbentuk periuk. Periuk yang ditemukan memiliki bentuk tepian terbuka keluar. Bentuk bibir datar, miring ke luar, dan cembung. Bentuk lain yang diperoleh dari hasil penggambaran adalah

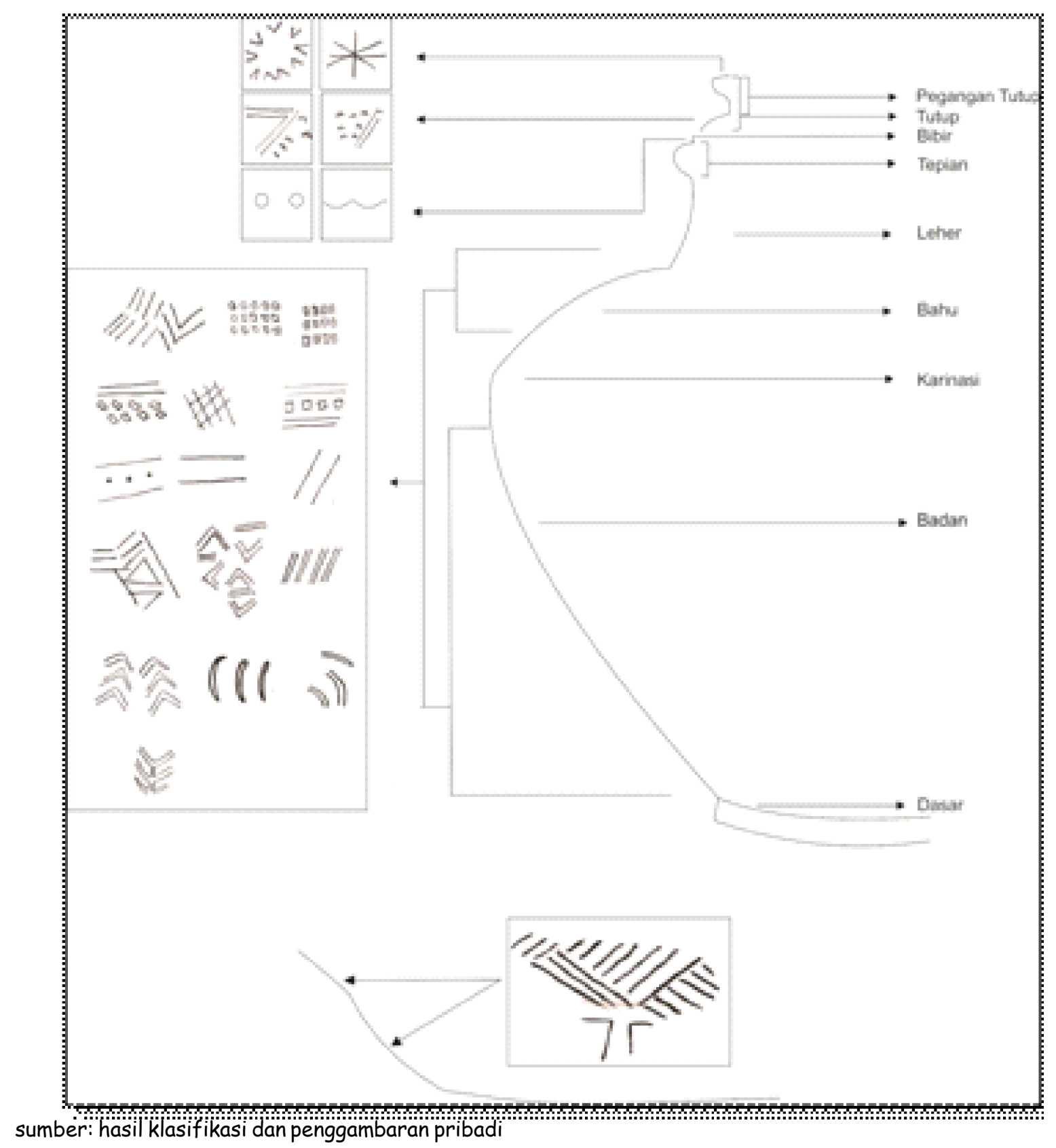

Gambar 5. Motif hias tembikar berdasarkan posisinya 
mangkuk dengan tepian terbuka keluar. Bagian bibir miring ke luar dan cembung. Bagian badan miring ke dalam dan cembung mirip periuk.

Bentuk tembikar lainnya yang tidak diperoleh dari hasil pengukuran dan penggambaran adalah kendi. Bentuk kendi diperoleh dari temuan fragmen cerat. Terdapat juga tembikar berbentuk piring. Terakhir adalah tembikar berbentuk persegi. Tembikar ini kemungkinan berbentuk kubus dengan bagian atas terbuka atau bagian tingginya lebih panjang dibandingkan bagian dasarnya. Tembikar ini juga memiliki tepian. Selain bentuk-bentuk tembikar tersebut, terdapat tembikar berbentuk tutup dengan pegangan. Tutup ini ukurannya cukup besar, sehingga tidak mungkin digunakan sebagai tutup kendi. Kemungkinan terbesar bagian tutup yang ditemukan digunakan menutup periuk atau mangkuk.

Fragmen tembikar Istana Almukarrammah memiliki motif hias yang beragam. Masing-masing bagian memiliki bentuk motif hias tersendiri, yaitu.

1. Bagian atas pegangan tutup memiliki motif hias garis-garis yang mengarah ke delapan penjuru mata angin. Terdapat juga motif cekungan yang menyerupai bentuk huruf $v$.

2. Bagian tutup terdiri dari motif duri ikan dan garis horisontal vertikal dikombinasi motif bulan sabit.

3. Bagian bibir memiliki motif lingkaran dan lengkungan ombak.

4. Bagian badan dan bahu memiliki jenis motif hias yang paling banyak di antaranya adalah motif jaring, motif garis horisontal dengan kombinasi lingkaran, belah ketupat, dan segi empat. Terdapat juga motif berbentuk huruf $\mathrm{v}$.

Motif hias tembikar Istana Almukarrammah dibuat dengan teknik gores atau incised, tekan dengan menggunakan cangkang kerang, kayu bulat, dan pukul dengan mengunakan alat tatap.

Tembikar Istana Almukarramah rata-rata didominasi oleh bentuk periuk. Periuk pada dasarnya adalah wadah. Terdapat beberapa tembikar yang memiliki jejak pakai berupa warna hitam pada permukaan luarnya. Warna hitam ini bukan merupakan bekas pembakaran ketika tembikar dibuat karena warna permukaan hasil pembakaran masih terlihat jelas. Dengan demikian terdapat satu bukti bahwa tembikar Istana Almukarrammah pernah digunakan sebagai wadah untuk memasak.

Fungsi lain dari temuan tembikar di Istana Almukarramah adalah sebagai alat upacara. Pendapat ini memang masih perlu didukung oleh hasil wawancara atau studi pustaka. Adanya temuan tembikar di sekitar Batu Kundur adalah latar belakang munculnya asumsi ini. Selain itu, banyaknya tembikar berhias yang ditemukan di TP 1 dan TP 2 juga dapat memperkuat dugaan ini. TP1 terletak tepat di bawah Batu Kundur, sedangkan TP 2 terletak antara 1 sampai 2 meter dari Batu Kundur.

Batu Kundur merupakan tanda awal pembangunan pusat negeri yang dilakukan oleh Demong Irawan (Tomi 2014: 158). Demong Irawan adalah pemimpin yang memindahkan Negeri Sepauk menuju wilayah yang disebut Senetang atau Sintang saat ini. Perpindahan ini disebabkan karena Sepauk sudah terlalu padat (Tomi 2014: 153). Tidak diketahui kapan perpindahan pusat negeri dari Sepauk ke Sintang. Batu Kundur sampai dengan saat ini masih dikeramatkan. Terbukti dengan adanya mitos jika batu ini digosok maka tidak lama kemudian akan terjadi hujan. Mitos inilah yang mungkin menyebabkan Batu Kundur digunakan sebagai lokasi upacara untuk memohon hujan.

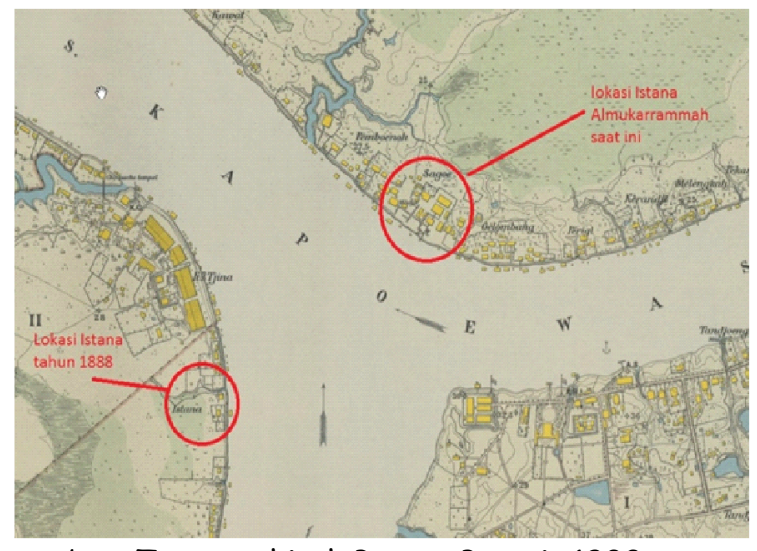

sumber: Topographisch Bureau Batavia 1988

Gambar 6.Lokasi Istana tahun 1888 dan Istana Almukarrammah saat ini 
Istana Almukarramah saat ini merupakan bangunan tahun 1937 (Atmojo 2010: 47). Bangunan istana yang berdiri tahun 1831 telah rusak (Atmojo 2010: 47). Berdasarkan sebuah peta Sintang yang dibuat oleh Belanda pada tahun 1888, lokasi istana pada tahun tersebut terletak di Desa Sungai Durian yang berdekatan dengan Kampung Cina (Topographisch Bureau Batavia 1988: tanpa halaman). Berdasarkan sumber peta tersebut, lokasi Istana Almukarramah saat ini, pada tahun 1888 masih merupakan lokasi permukiman (lihat gambar 6). Dengan demikian bangunan istana tahun 1937 bukan menggantikan bangunan istana lama yang terletak pada lokasi yang sama. Hal ini disebabkan karena pada tahun 1888 , istana masih terletak di Desa Sungai Durian. Perpindahan dari istana lama ke istana baru tampaknya membawa serta Batu Kundur.

Jika asumsi terkait fungsi tembikar Istana Almukarrammah sebagai media upacara, maka umur dari tembikar Istana Almukarrammah masih sangat muda, yaitu berkisar 1900-an. Sebaran fragmen tembikar di seluruh halaman depan dan belakang Istana Almukarrammah sangat mungkin terkait dengan fungsi lokasi ini sebelum menjadi istana. Berdasarkan peta keluaran Biro Topografi Batavia di atas, wilayah di sekitar lokasi Istana Almukarramah saat ini pada tahun 1888 didominasi oleh rawa semak belukar. Tepian Sungai Kapuas dimanfaatkan sebagai pemukiman muslim yang sangat padat. Terdapat nama-nama lokasi seperti Pemboenoeh, Sagoe, Gelombang, Perigi, Kerandji, dan Melengkah. Adanya pemukiman di lokasi ini menunjukkan bahwa tembikar di Istana Almukarrammah berfungsi sebagai benda peralatan sehari-hari.

\section{PENUTUP}

Tembikar yang ditemukan di Istana Almukarramah dibuat dengan berbagai teknik. Teknik pembentukan tembikar yang digunakan adalah spiral, tekan atau pijit, tatap pelandas, roda putar cepat dan lambat. Terdapat juga tembikar yang dibentuk dengan menggunakan teknik gabungan antara tekan atau pijit dengan roda putar cepat, tatap pelandas dengan roda putar lambat maupun roda putar cepat. Pada saat tembikar telah terbentuk, tembikar kemudian dibakar baik menggunakan tungku maupun pembakaran di luar ruangan. Berdasarkan warna tembikar yang ditemukan, sebagian besar tembikar belum mencapai oksidasi sempurna, warna tembikar yang didominasi abu tua menunjukkan bahwa oksidasi kurang sempurna. Hadirnya tembikar berwarna putih menunjukkan bahwa bahan baku yang digunakan kurang kandungan besi.

Tembikar Istana Almukarrammah sebagian besar berbentuk periuk dan mangkuk, namun terdapat juga tembikar yang berbentuk piring dan kendi. Terdapat juga tembikar yang berbentuk tutup dengan pegangan dan tembikar berbentuk persegi. Beberapa tembikar yang ditemukan tampaknya memiliki motif hias. Masing masing motif hias ditempatkan dalam posisi tertentu. Bagian atas pegangan tutup memiliki motif hias garis-garis yang mengarah ke delapan penjuru mata angin. Terdapat juga motif cekungan yang menyerupai bentuk huruf v. Bagian tutup terdiri dari motif duri ikan dan garis horizontal vertikal dikombinasi motif bulan sabit. Bagian bibir memiliki motif lingkaran dan lengkungan ombak. Bagian badan dan bahu memiliki jenis motif hias yang paling banyak di antaranya adalah motif jaring, motif garis horizontal dengan kombinasi lingkaran, belah ketupat, dan segi empat. Terdapat juga motif berbentuk huruf $v$.

Di Kalimantan, kawasan pertemuan sungai merupakan tempat yang strategis sebagai lokasi pemukiman. Lokasi pertemuan sungai pada umumnya dimanfaatkan sebagai pemukiman berlanjut. Kebiasaan hidup berpindah menyebabkan lokasi-lokasi pertemuan sungai dimanfaatkan oleh kelompok masyarakat yang berbeda. Lokasi Istana Almukarramah saat ini, pada tahun 1888 masih dimanfaatkan sebagai pemukiman. Masyarakat yang tinggal di lokasi inilah yang diduga telah meninggalkan jejak-jejak tembikar dan artefak lainnya.

Kondisi lingkungan sekitar Istana Almukarramah sebelum tahun 1888 adalah rawa semak belukar. Rawa semak belukar ini kemungkinan besar juga ditumbuhi oleh pohon sagu. Asumsi ini diambil dari toponimi Sagoe 
yang merupakan nama lokasi Istana Almukarammah pada tahun 1888. Masyarakat di sekitar lokasi ini tampaknya telah memanfaatkan sagu sebagai sumber subsistensi. Artefak beliung yang ditemukan pada tahun 1996 sangat mungkin dimanfaatkan untuk memotong pohon sagu. Masyarakat yang tinggal di lokasi ini bukan merupakan golongan bangsawan istana sehingga tidak heran jika sebagian besar tembikar yang ditemukan dapat dikategorikan pada kualitas yang rendah sampai sedang.

Perpindahan Istana Almukarramah dari Sungai Durian ke lokasi saat ini disebabkan karena sebagian besar komunitas muslim tinggal di sekitar wilayah yang disebut Sagoe, sedangkan lokasi yang lama merupakan lokasi pemukiman masyarakat Tionghoa. Perpindahan ini turut membawa Batu Kundur sebagai tanda batas negeri.

\section{DAFTAR PUSTAKA}

Atmojo, Bambang Sakti. 2010. "Kepurbakalaan Islam di Sintang dan Ketapang, Kalimantan Barat." Berita Penelitian Balai Arkeologi Banjarmasin 4(1): 44-68.

Noerwidi, Sofwan. 2007. "Beberapa Seni Kriya Elemen Penanda Kehadiran Austronesia di Kepulauan Indonesia." HIm. 187-205 dalam Kriyamika: Melacak Akar dan Perkembangan Kriya. Yogyakarta: Jurusan Arkeologi Fakultas IImu Budaya Universitas Gajah Mada.

Orton, Cilve, Paul Tyers, dan Alan Vice. 1993. Poetry in Archaeology. New York: Cambridge University Press.

Rice, Prudence M. 1987. Pottery Analysis A Sourcebook. London: the University of Chicago Press.

Solheim, Wilhelm G. 1965. "The Function of Ceramics in Southeast Asia: from the Present to the Past." HIm 254-273 dalam
Ceramic and Man, editor Frederick Matson. Chicago: Aldine.

Simanjuntak, Truman. Dwi Yani Yuniawati, Naniek Harkantiningsih, Endang Sri Hardianti, Sonny Wibisono, dan Fadhila Arifin Aziz. 2008. Metode Penelitian Arkeologi. Jakarta: Pusat Penelitian Arkeologi Nasional.

Tomi. 2014. Pasak Negeri Kapuas 1616-1822. Jakarta: Feliz Books.

Wahyudi, Wanny Raharjo. 2012. Tembikar Upacara di Candi-Candi Jawa Tengah Abad ke-8-10. Jakarta: Wedatama Widya Sastra.

Yondri, Lutfi. 2000. "Penjajakan Hunian Belanjut di Tepian DAS Kapuas". Kronik Arkeologi (2)1:10-31.

Topographisch Bureau Batavia. 1988. "Kaart van den vierkanten paal (I en II) gouvernements grondgebied te Sintang". Diunduh 10 Agustus 2016 (http://www.media-kitlv.nl/allmedia/indeling/detail/form/advanced/start/ 167?q_searchfield=sintang). 

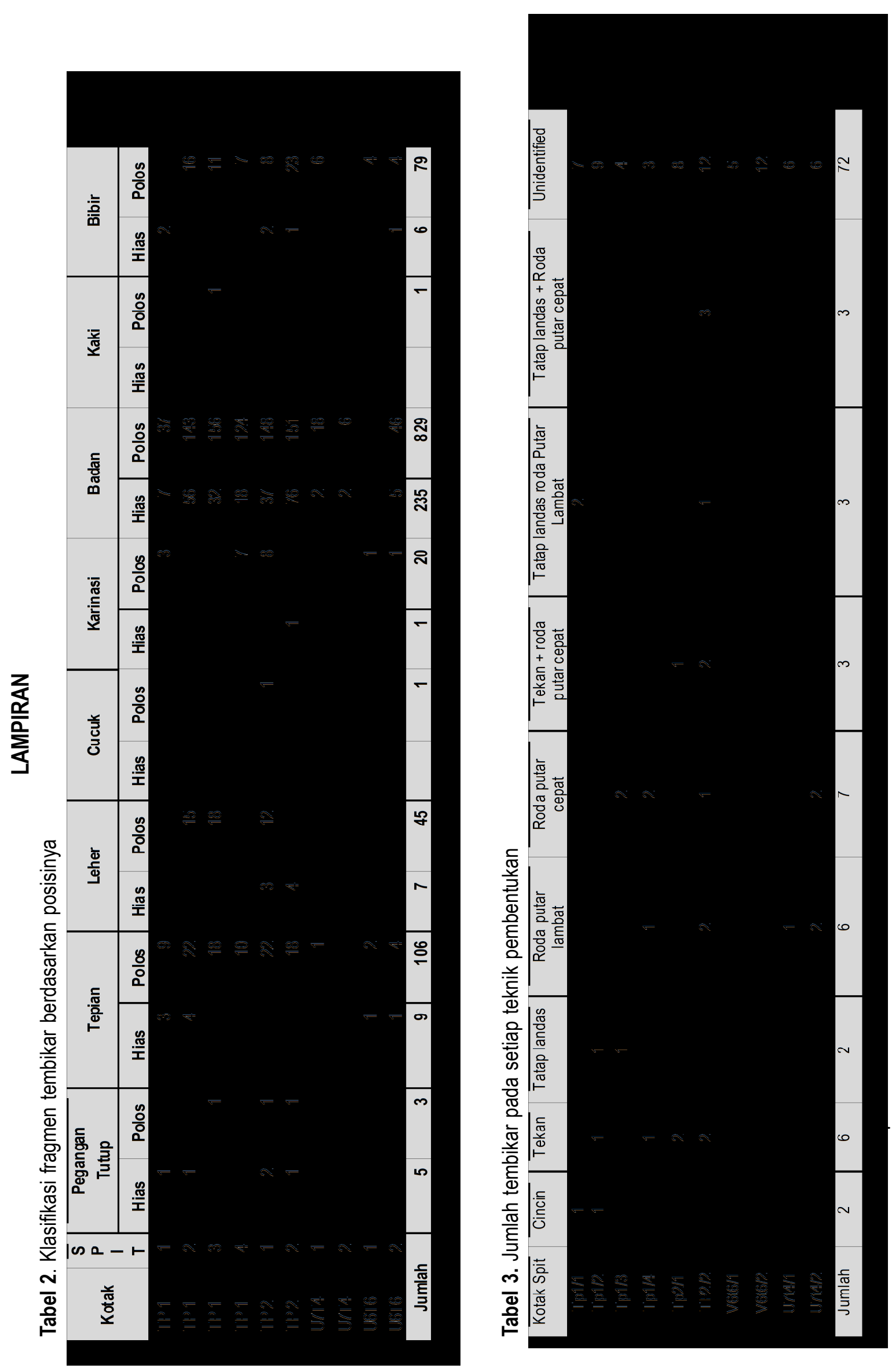


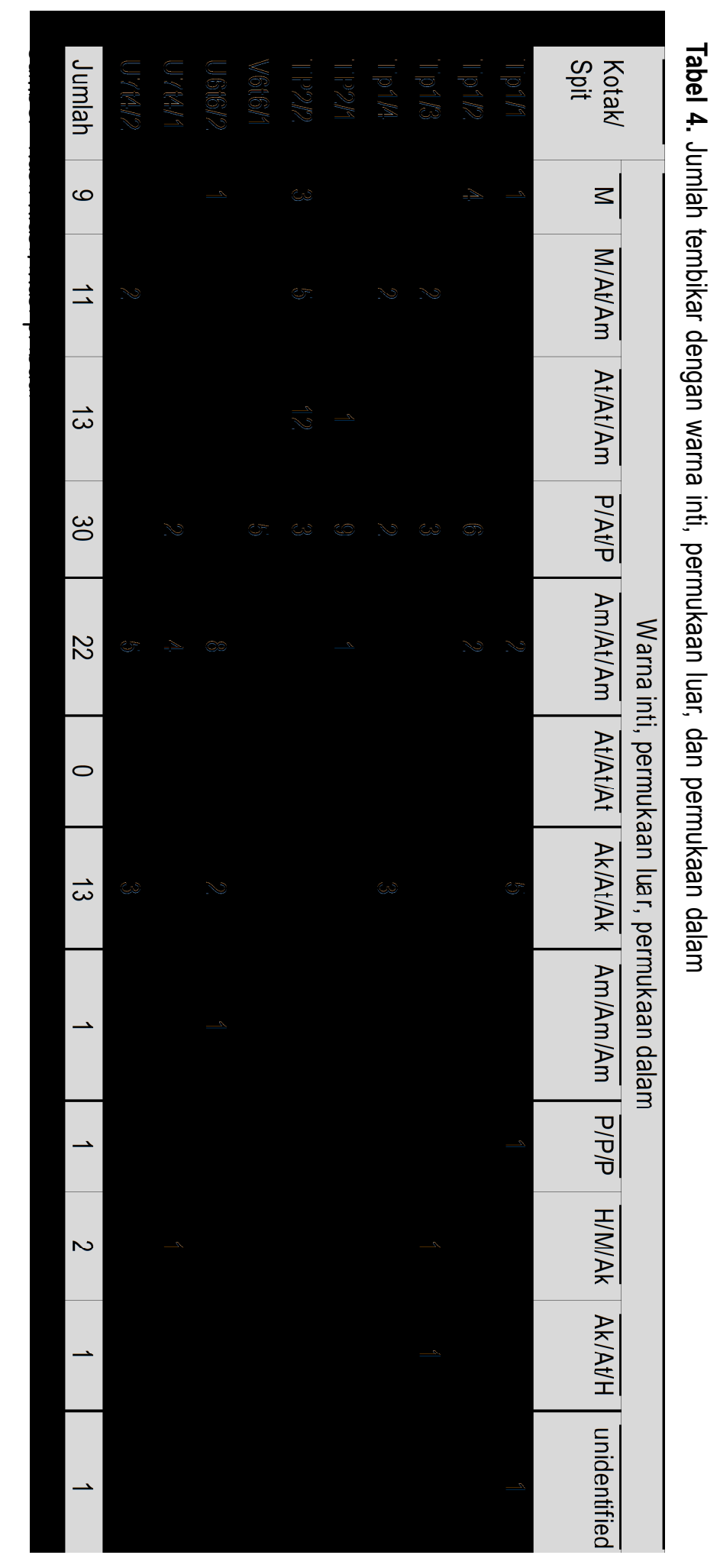

